\title{
Outcomes of thymoma after multimodal therapy and determinants of survival: A 16-year experience of a tertiary cancer center
}

\author{
Multimodal tedavi sonrası timoma hastalığının seyri ve hastalarda sağkalımın belirleyicileri: \\ Üçüncü basamak kanser merkezinin 16 yıllık deneyimi
}

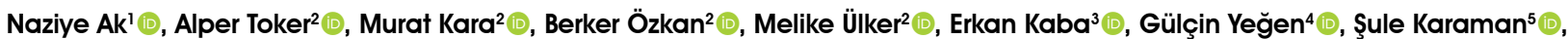

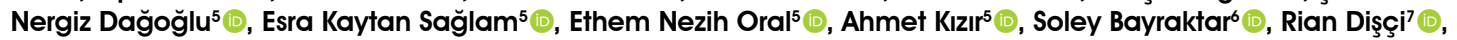

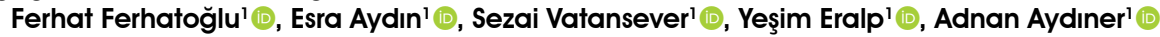

Institution where the research was done:

Istanbul University, Institute of Oncology, Istanbul, Turkey

\section{Author Affiliations:}

'Department of Medical Oncology, Istanbul University, Institute of Oncology, Istanbul, Turkey ${ }^{2}$ Department of Thoracic Surgery, Istanbul University, Istanbul Medical Faculty, Istanbul, Turkey ${ }^{3}$ Department of Thoracic Surgery, Istanbul Florence Nightingale Hospital, Istanbul, Turkey ${ }^{4}$ Department of Pathology, Istanbul University, Istanbul Medical Faculty, Istanbul, Turkey ${ }^{5}$ Department of Radiation Oncology, Istanbul University, Institute of Oncology, Istanbul, Turkey ${ }^{6}$ Department of Medical Oncology, Biruni University School of Medicine, Istanbul, Turkey

'Department of Biostatistical Science, Beykent University, Istanbul, Turkey

\section{ABSTRACT}

Background: In this study, we aimed to evaluate the factors that contribute to survival outcomes in patients with thymoma treated with multimodal approaches. Methods: A total of 203 patients (105 males, 98 females; median age: 49 years; range, 17 to 77 years) with Masaoka-Koga Stage II-IV thymoma between January 2002 and December 2018 were retrospectively analyzed. Data including diagnosis of myasthenia gravis, diagnosis of diabetes mellitus, disease stage, histological type of tumor, capsule invasion and surgical margin status, lymphadenectomy, adjuvant radiotherapy or chemotherapy, time from surgery to the first day of adjuvant treatment, length of hospital stay, and overall and disease-free survival rates were recorded.

Results: Of the patients, 91 had Stage II, 67 had Stage III, and 45 had Stage IV disease. A total of 123 patients $(61 \%)$ had myasthenia gravis. Seventy-six patients received adjuvant radiotherapy and 48 patients received either neoadjuvant $(n=35)$ or adjuvant $(n=25)$ chemotherapy. Higher disease stage, presence of R1 resection, and treatment with chemotherapy were significant factors for decreased disease-free survival time. Older age, higher disease stage, longer postoperative hospital stay, chemotherapy, and disease recurrence were effective contributors to decreased overall survival time. Adjuvant radiotherapy had a statistically significant positive effect on overall survival only in patients with completely resected Stage IV disease (five-year overall survival: $94.7 \%$ vs. $79.1 \%$, respectively; $\mathrm{p}=0.015$ ). In the multivariate analysis, older age (hazard ratio: 4.26 ), higher disease stage (hazard ratio: 2.95), and longer hospitalization time (hazard ratio: 3.81) were significant prognostic factors for overall survival. Patients with local recurrence who underwent complete resection had a survival time comparable to non-recurrent patients $(\mathrm{p}=0.753)$.

Conclusion: For patients with thymoma, higher disease stage, age $\geq 50$ years, longer hospitalization, and need for chemotherapy are associated with worse survival rates. Adjuvant chemotherapy has a positive impact on Stage IV disease. Resection of recurrent lesions has a valuable impact on survival.

Keywords: Aggressive surgery, chemotherapy, Masaoka-Koga Staging, radiotherapy, survival, thymoma.

\section{$\ddot{O} Z$}

Amaç: $\mathrm{Bu}$ çalışmada, multimodal yaklaşımlar ile tedavi edilen timoma hastalarının sağkalım sonuçlarına katkıda bulunan faktörler değerlendirildi. Calıșma planı: Ocak 2002 - Aralık 2018 tarihleri arasında Masaoka-Koga Evre II-IV timomalı toplam 203 hasta (105 erkek, 98 kadın; medyan yaş: 49 yıl; dağılım, 17-77 yıl) retrospektif olarak incelendi. Myastenia gravis tanısı, diabetes mellitus tanısı, hastalık evresi, tümörün histolojik türü, kapsül invazyonu ve cerrahi sınır durumu, lenfadenektomi, adjuvan radyoterapi veya kemoterapi, cerrahiden adjuvan tedavinin ilk gününe kadar geçen süre, hastanede yatış süresi ve genel ve hastalıksız sağkalım oranları kaydedildi.

Bulgular: Hastaların 91'inde Evre II, 67'sinde Evre III ve 45'inde Evre IV hastalık izlendi. Toplam 123 hastada (\%61) myastenia gravis vardı. Yetmiş altı hastaya adjuvan radyoterapi ve 48 hastaya neoadjuvan $(n=35)$ veya adjuvan $(n=25)$ kemoterapi verildi. Yüksek hastalık evresi, R1 rezeksiyon varlığı ve kemoterapi azalmış hastalıksız sağkalım süresinin anlamlı faktörleriydi. İleri yaş, yüksek hastalık evresi, ameliyat sonrası uzun süreli hastane yatış1, kemoterapi ve hastalık nüksü genel sağkalım süresinin azalmasına katkıda bulunan faktörlerdi. Yalnızca tam rezeke Evre IV hastalığ 1 olan hastalarda, adjuvan radyoterapinin genel sağkalım üzerinde istatistiksel olarak anlamlı bir pozitif etkisi vardı (beş yıllık genel sağkalım: sırasıyla \%79.1'e kıyasla \%94.7; p=0.015). Çok değişkenli analizde ileri yaş (risk oranı: 4.26), yüksek hastalık evresi (risk oranı: 2.95) ve daha uzun hastanede yatış süresi (risk oranı: 3.81) genel sağkalımın anlamlı prognostik faktörleriydi. Tam rezeksiyon uygulanmış lokal nüks saptanan hastalardaki sağkalım süresi, hiç nüks saptanmayan hastalar ile benzer bulundu $(\mathrm{p}=0.753)$.

Sonuç: Timomalı hastalarda yüksek hastalık evresi, $\geq 50$ yaş, daha uzun süreli hastanede yatış ve kemoterapi ihtiyacı, daha kötü sağkalım oranları ile ilişkilidir. Adjuvan radyoterapi, Evre IV hastalık üzerinde olumlu etkiye sahiptir. Tekrarlayan lezyonların rezeksiyonunun sağkalım üzerinde önemli bir etkisi vardır.

Anahtar sözcükler: Agresif cerrahi, kemoterapi, Masaoka-Koga Evrelemesi, radyoterapi, sağkalım, timoma.

Received: July 24, 2020 Accepted: September 18, 2020 Published online: October 20, 2021

Correspondence: Naziye Ak, MD. İstanbul Üniversitesi Onkoloji Enstitüsü, Tıbbi Onkoloji Anabilim Dalı, 34093 Fatih, İstanbul, Türkiye. Tel: +90 551 - 1022866 e-mail: naziyeak@hotmail.com

Cite this article as:

Ak N, Toker A, Kara M, Özkan B, Ülker M, Kaba E, et al. Outcomes of thymoma after multimodal therapy and determinants of survival: A 16-year experience of a tertiary cancer center. Turk Gogus Kalp Dama 2021;29(4):487-495 
Thymomas are the most commonly diagnosed mediastinal tumors that present with anterior mediastinal masses...$^{1,2]}$ Thymomas typically occur between 40 and 70 years of age, with similar incidences in both sexes. ${ }^{[3]}$ Approximately 30 to $50 \%$ of patients with thymoma have myasthenia gravis (MG), and a wide range of other autoimmune paraneoplastic syndromes have been also reported. ${ }^{[4]}$ The World Health Organization's (WHO) classification of thymic tumors was revised in 2015 and divided into six types: A, AB, B1, B2, B3, and thymic carcinoma. ${ }^{[5]}$ The American Joint Committee on Cancer (AJCC) and the Masaoka-Koga staging system are two widely used staging modalities. ${ }^{[6-8]}$ and surgery with a clear margin is the primary treatment modality. ${ }^{[9]}$ The role of adjuvant radiotherapy (RT) remains controversial due to conflicting survival results, particularly after R0-resection for advanced stage thymomas. ${ }^{[10-12]}$

There is a dearth of randomized studies showing benefits of adjuvant therapy in completely resected patients, despite the high sensitivity of the tumor to chemotherapeutic agents. Due to the rarity of this tumor, prospective studies are unlikely and existing data mostly rely on retrospective or institutional reports, with current guidelines based on expert opinions. In the present study, we, therefore, aimed to evaluate the factors that contribute to outcomes in patients with thymoma treated with multimodal therapy.

\section{PATIENTS AND METHODS}

This single-center, retrospective study was conducted at Istanbul University, Institute of Oncology, Department of Medical Oncology between January 2002 and December 2018. Patients with Masaoka-Koga Stage II-IV thymoma were screened. Inclusion criteria were as follows: (i) patients with pathologically confirmed Masaoka-Koga Stage II-IV thymoma, (ii) patients with adequate follow-up, and (iii) patients who completed all suggested treatment modalities for standardization. Exclusion criteria were as follows: (i) patients with Masaoka-Koga Stage I thymoma, (ii) final pathology that also revealed a squamous cell carcinoma, (iii) incomplete clinical or pathological data, (iv) presence of synchronous active malignancy, and (v) refusal to give consent for the study. Accordingly, a total of 203 patients (105 males, 98 females; median age: 49 years; range, 17 to 77 years) were included in the study. A written informed consent was obtained from each patient. The study protocol was approved by the Istanbul University, Istanbul Faculty of Medicine Ethics Committee (No: 62576/2020). The study was conducted in accordance with the principles of the Declaration of Helsinki.

We performed histopathological confirmation before the definitive treatment, either via Tru-cut biopsy, mediastinotomy, or video-assisted thoracic surgery (VATS) biopsy, in patients whose thymic mass could not be resected with minimally invasive VATS. Lung resections, including lobectomies, were performed when there was an invasion of the lung or the hilar vessels of the lung. Parietal pleurectomy and/or partial or total diaphragmatic and pericardial resections were performed when there was an invasion, or thymoma implants were recognized. The phrenic nerve was sacrificed, when there was a unilateral invasion, and the diaphragm was plicated on the ipsilateral side. When the phrenic nerve was invaded bilaterally, the residual tumor was left behind on both or either side of the nerve. The indications for lymph node dissection were as follows: $(i)$ pathological nodal enlargement in tomography and/or increased uptake in positron emission tomography, (ii) detection of positive lymph nodes during dissection, (iii) all open surgeries performed after 2014. When complete resection seemed impossible (according to the pre-surgical radiological assessment), we carefully discussed it with a multidisciplinary council and opted for neoadjuvant chemotherapy (CT) as a part of the curative-intent strategy. Two definite indications for neoadjuvant CT were the unfeasibility of R0 resection and the presence of a tumor too close to the main vascular structures. Neoadjuvant CT was omitted after experiencing difficulties in dissection and vascular reconstructions. Clinical restaging after induction CT was performed with computed tomography after the third cycle, and the decision for surgery suitability was made within a multidisciplinary council. For patients with an insufficient response, treatment continued until surgery could be performed. The Masaoka-Koga Stage system was used for staging, and the WHO classification system was used for histological classification. When the results were reported as mixed histological types, the tumor was reclassified according to the most histologically aggressive type. To illustrate, when the tumor had B1 and B3 components, the tumor was classified as type B3. Patients who recurred with resectable disease underwent three types of surgeries: (i) local excision of pleural, pericardial, and diaphragmatic implants, (ii) pleurectomy/decortication, (iii) chest wall/diaphragmatic resection and reconstruction. In general, posterolateral thoracotomy and median sternotomy were used in this group. A single incision with double-level thoracotomy was applied 
to achieve implantations. In addition, pericardial defects were reconstructed with polypropylene or polytetrafluoroethylene (PTFE) patches and diaphragmatic defects with PTFE patches.

Regarding the decisions for postoperative treatment, stage and completeness of resection were the most relevant criteria considered, followed by histological evaluation. We used three-dimensional conformal radiotherapy (RT) with doses of 50.4 Gy/1.8-2 Gy per fraction in adjuvant CT and 54 to $56 \mathrm{~Gy} / 1.8-2 \mathrm{~Gy}$ per fraction for microscopically positive resection margins and neoadjuvant $\mathrm{CT}$. The $\mathrm{CT}$ regimen was based on the physician's preference. The regimens used for neoadjuvant and adjuvant settings were CAP (cyclophosphamide $500 \mathrm{mg} / \mathrm{m}^{2}$, cisplatin $50 \mathrm{mg} / \mathrm{m}^{2}$, doxorubicin $50 \mathrm{mg} / \mathrm{m}^{2}$, intravenous day one every

Table 1. Baseline characteristics of patients and treatment modalities

\begin{tabular}{|c|c|c|c|c|c|c|c|}
\hline \multirow[b]{2}{*}{ Characteristics } & \multicolumn{2}{|c|}{ Total } & \multicolumn{3}{|c|}{ Masaoka-Koga Stage } & \multicolumn{2}{|c|}{ Resection type* } \\
\hline & $\mathrm{n}$ & $\%$ & II & III & IV & R0 & R1 \\
\hline \multicolumn{8}{|l|}{ Age (year) } \\
\hline$<50$ & 106 & 52.2 & 49 & 32 & 25 & 102 & 4 \\
\hline$\geq 50$ & 97 & 47.8 & 42 & 35 & 20 & 88 & 5 \\
\hline \multicolumn{8}{|l|}{ Sex } \\
\hline Male & 105 & 51.7 & 48 & 32 & 25 & 97 & 6 \\
\hline Female & 98 & 48.3 & 43 & 35 & 20 & 93 & 3 \\
\hline \multicolumn{8}{|l|}{ MG } \\
\hline Yes & 123 & 60.6 & 63 & 38 & 22 & 117 & 4 \\
\hline No & 80 & 39.4 & 28 & 29 & 23 & 73 & 4 \\
\hline \multicolumn{8}{|c|}{$\begin{array}{l}\text { Acetylcholine receptor antibodies } \\
\text { (Patients with MG) }\end{array}$} \\
\hline Yes & 113 & 91.9 & 56 & 37 & 20 & 107 & 4 \\
\hline No & 10 & 8.1 & 7 & 1 & 2 & 10 & 0 \\
\hline \multicolumn{8}{|l|}{ WHO histology } \\
\hline $\mathrm{A} \dagger$ & 14 & 6.9 & 7 & 5 & 2 & 13 & 0 \\
\hline $\mathrm{AB}$ & 21 & 10.3 & 16 & 3 & 2 & 20 & 1 \\
\hline $\mathrm{B} 1 \dagger$ & 39 & 19.2 & 24 & 7 & 8 & 38 & 0 \\
\hline $\mathrm{B} 2 \dagger$ & 75 & 36.9 & 28 & 28 & 19 & 70 & 4 \\
\hline $\mathrm{B} 3 \dagger$ & 50 & 24.6 & 13 & 23 & 14 & 45 & 4 \\
\hline Micronodular thymoma & 1 & 0.5 & 1 & 0 & 0 & 1 & 0 \\
\hline Not classified & 3 & 1.5 & 2 & 1 & 0 & 3 & 0 \\
\hline \multicolumn{8}{|l|}{ NACT type* } \\
\hline Cis/etoposide & & & 1 & 6 & 1 & 8 & 0 \\
\hline CAP & 35 & 17.6 & 2 & 6 & 17 & 20 & 2 \\
\hline Pac/carbo & & & 0 & 1 & 1 & 4 & 1 \\
\hline \multicolumn{8}{|l|}{ Adjuvant CT type* } \\
\hline Cis/etoposide & & & 0 & 2 & 7 & 8 & 1 \\
\hline CAP & 25 & 12.6 & 0 & 6 & 6 & 11 & 1 \\
\hline Pac/carbo & & & 1 & 1 & 2 & 4 & 0 \\
\hline \multicolumn{8}{|l|}{ Adjuvant RT* } \\
\hline 50 & & & 21 & 15 & 14 & 49 & 1 \\
\hline 54 & 76 & 38.2 & 5 & 11 & 7 & 18 & 5 \\
\hline 56 & & & 0 & 1 & 2 & 0 & 3 \\
\hline \multicolumn{8}{|l|}{ Surgery after recurrence* } \\
\hline Yes & 21 & 10.6 & 3 & 6 & 12 & 19 & 2 \\
\hline
\end{tabular}

MG: Myasthenia gravis; WHO: World Health Organization; NACT: Neoadjuvant chemotherapy; Cis: Cisplatin; CAP: Cyclophosphamide/adriamycin/cisplatin; CT: Chemotherapy; RT: Radiotherapy; * Total N: 199 with exclusion of four inoperable patients; $\uparrow$ Histology of a metastatic patient. 
Table 2. Characteristics of patients with lymph node involvement

\begin{tabular}{lcccccc}
\hline $\begin{array}{l}\text { Patient } \\
\text { no }\end{array}$ & $\begin{array}{c}\text { Age } \\
(\text { year })\end{array}$ & $\begin{array}{c}\text { Tumor size } \\
(\mathrm{mm})\end{array}$ & Histology type & $\begin{array}{c}\text { Masaoka-Koga } \\
\text { Stage }\end{array}$ & $\begin{array}{c}\text { Cervical lymph } \\
\text { node dissection }\end{array}$ & $\begin{array}{c}\text { Station of positive } \\
\text { lymph nodes }\end{array}$ \\
\hline 1 & 36 & 80 & Thymoma type B1 & Stage 4A & + & Cervical \\
2 & 42 & 71 & Thymoma type B2 & Stage 4A & - & $4 \mathrm{R}$ \\
3 & 44 & 50 & Thymoma type B2 & Stage 3 & - & $4 \mathrm{R}$ \\
4 & 33 & 80 & Thymoma type B3 & Stage 4A & + & Cervical 4R \\
5 & 55 & 60 & Thymoma type B3 & Stage 3 & - & $2 \mathrm{~L}$ \\
\hline
\end{tabular}

three weeks), CE (cisplatin $75 \mathrm{mg} / \mathrm{m}^{2}$ intravenous day one, etoposide $100 \mathrm{mg} / \mathrm{m}^{2}$ intravenous day 1-3 every 3 weeks), and paclitaxel with carboplatin (paclitaxel $80 \mathrm{mg} / \mathrm{m}^{2}$ intravenous day 1 , carboplatin AUC 2 intravenous day 1 weekly).

Patients who did not undergo complete surgery during the course of their disease were excluded from survival analysis with the aim of preserving accurate survival factors. The overall survival (OS) was defined from the date of histological diagnosis to the date of death from any cause. Disease-free survival (DFS) was defined from the date of histological diagnosis until recurrence.

Data including median age, sex, diagnosis of MG, diagnosis of diabetes mellitus (DM), MasaokaKoga Stage, WHO histological type of tumor, capsule invasion and surgical margin status, lymphadenectomy, adjuvant RT or CT, days from surgery to the first day of adjuvant treatment (before and after 60 days), and length of hospital stay were analyzed.

\section{Statistical analysis}

Statistical analysis was performed using the IBM SPSS version 20.0 software (IBM Corp., Armonk, NY, USA). Descriptive data were expressed in mean \pm standard deviation (SD), median (min-max) or number and frequency, where applicable. The distribution of categorical variables was compared using the chi-square test, while continuous variables were compared after normality tests using the Mann-Whitney $U$ or Kruskal-Wallis $H$ test. Multivariate Cox regression analysis with $95 \%$ confidence interval (CI) was used to evaluate the effects of risk factors on survival. The Kaplan-Meier method was used for survival analysis, and factors were compared using the log-rank test. A $p$ value of $<0.05$ was considered statistically significant.

\section{RESULTS}

\section{Demographic data}

The most common complaints were myastheniarelated symptoms $(n=70,34.5 \%)$, while a total of

Table 3. Characteristics of patients with lymph node involvement

\begin{tabular}{lcc}
\hline Characteristic & $\mathrm{n}$ & $\%$ \\
\hline Sex & & \\
$\quad$ Male & 10 & 47.6 \\
Female & 11 & 52.4 \\
Type of surgery & & \\
$\quad$ Pleural implantation/pleurectomy & 12 & 57.1 \\
Cardiac implantation & 5 & 23.8 \\
Diaphragmatic implantation/reconstruction & 11 & 52.4 \\
Chest wall resection/ reconstruction & 4 & 19 \\
Complications & & \\
None & 11 & 52.4 \\
Pneumonia & 4 & 19 \\
Wound infection & 4 & 19 \\
Hemorrhage (without revision) & 3 & 14.3 \\
Cardiac arrhythmia & 2 & 9.5 \\
\hline
\end{tabular}


$15.3 \%$ of the patients $(n=31)$ were asymptomatic. Other presenting symptoms included fatigue, mass-related symptoms such as coughing, chest pain, hoarseness, and dyspnea. Totally $123(61 \%)$ patients had associated MG during any course of the disease, most frequently in B2 thymomas $(n=53,43.1 \%$ of patients with $M G)$. Other autoimmune diseases associated with disease were hypothyroidism, hypogammaglobulinemia, uveitis, ankylosing spondylitis, and pure red cell aplasia. Type
B2 and B3 thymomas were more invasive, and had more cases at either Stage III or IV $(\mathrm{p}<0.001)$. Four patients $(2 \%)$ had metastatic disease.

\section{Treatment modalities}

The baseline disease characteristics of the patients, treatment modalities according to stage, and resection data are shown in Table 1 . We operated the majority of patients within the first

Table 4. Univariate survival analysis of patients $(n=199)^{*}$

\begin{tabular}{|c|c|c|c|c|c|c|}
\hline \multirow[b]{2}{*}{ Factors } & \multicolumn{3}{|c|}{ Disease free survival results } & \multicolumn{3}{|c|}{ Overall survival results } \\
\hline & $\begin{array}{c}\% \text { of } 5 \text {-years } \\
\text { survival }\end{array}$ & SE & $p^{\dagger}$ & $\begin{array}{c}\% \text { of } 5 \text {-years } \\
\text { survival }\end{array}$ & SE & $p \dagger$ \\
\hline \multicolumn{7}{|l|}{ Age } \\
\hline$<50$ & 79 & 4.6 & \multirow{2}{*}{0.260} & 96.5 & 2 & \multirow{2}{*}{0.043} \\
\hline$\geq 50$ & 89.4 & 3.8 & & 86.3 & 4.4 & \\
\hline \multicolumn{7}{|l|}{ Sex } \\
\hline Female & 85.1 & 4.4 & \multirow{2}{*}{0.876} & 92.2 & 3.1 & \multirow{2}{*}{0.660} \\
\hline Male & 82.3 & 4.3 & & 91.5 & 3.5 & \\
\hline \multicolumn{7}{|c|}{ Myasthenia gravis } \\
\hline No & 79.9 & 5.9 & \multirow{2}{*}{0.566} & 88.8 & 4.9 & \multirow{2}{*}{0.843} \\
\hline Yes & 85.4 & 3.6 & & 94.4 & 2.2 & \\
\hline \multicolumn{7}{|l|}{ Histology } \\
\hline A & 100 & 0 & \multirow{5}{*}{0.887} & 87.5 & 11.7 & \multirow{5}{*}{0.583} \\
\hline $\mathrm{AB}$ & 87.8 & 8.1 & & 100 & 0 & \\
\hline B1 & 84.2 & 6.5 & & 91.6 & 4.7 & \\
\hline B2 & 76.7 & 6.0 & & 92.8 & 3.5 & \\
\hline B3 & 85.4 & 6.1 & & 91.4 & 5 & \\
\hline \multicolumn{7}{|c|}{ Masaoka-Koga Stage } \\
\hline II & 95.7 & 2.4 & \multirow{3}{*}{$<0.001$} & 96 & 2.3 & \multirow{3}{*}{0.003} \\
\hline III & 89 & 4.7 & & 88.4 & 5 & \\
\hline IV & 46.7 & 9.5 & & 88.2 & 5.6 & \\
\hline \multicolumn{7}{|c|}{ Hospitalization } \\
\hline$\leq 8$ & 90.8 & 2.8 & \multirow{2}{*}{0.088} & 95.6 & 1.9 & \multirow{2}{*}{0.008} \\
\hline$>8$ & 74.3 & 7.9 & & 79.8 & 6.9 & \\
\hline \multicolumn{7}{|l|}{ Resection } \\
\hline R0 & 84.9 & 3.1 & \multirow{2}{*}{0.042} & 92.2 & 2.3 & \multirow{2}{*}{0.823} \\
\hline R1 & 47.4 & 22.8 & & 80 & 17.9 & \\
\hline \multicolumn{7}{|c|}{ Adjuvant radiotherapy } \\
\hline No & 87.6 & 3.7 & \multirow{2}{*}{0.231} & 90.5 & 3.3 & \multirow{2}{*}{0.400} \\
\hline Yes & 78.5 & 5.2 & & 93.6 & 3.7 & \\
\hline \multicolumn{7}{|c|}{ Adjuvant chemotherapy } \\
\hline No & 91.6 & 2.6 & $<0001$ & 90.3 & 2.7 & \\
\hline Yes & 37.3 & 11.5 & $<0.001$ & 100 & 0 & 0.970 \\
\hline Neoadjuva & & & & & & \\
\hline No & 88.8 & 2.8 & 1 & 91.5 & 2.6 & 146 \\
\hline Yes & 54.0 & 11.0 & & 86.9 & 7.2 & \\
\hline
\end{tabular}

$\dagger$ Log-rank test; SE: Standard error; * Total n: 199 with exclusion of four inoperable patients. 
two months post-neoadjuvant $\mathrm{CT}$, with a median of 51 days. We performed $103(50.7 \%)$ upper partial or total sternotomy operations, 54 (26.6\%) VATS, including unilateral, bilateral, and subxiphoid VATS approaches, $37(18.2 \%)$ thoracotomies, and five $(2.5 \%)$ robot-assisted thoracoscopic surgery. Overall, most patients $(n=190)$ underwent R0 resection, and nine patients received R1-resection. During surgery, frozen sections confirmed complete resection without a suspicion of residual tumor. Thirty-five (17.25\%) patients were treated with neoadjuvant $\mathrm{CT}$, nine of whom underwent concomitant RT. However, none of them showed a complete pathological response in the final pathology. Superior vena cava resection and reconstruction were performed in $22(1.1 \%)$ patients. We performed lymphadenectomy in 95 (4.7\%) patients, of which five showed metastatic lymph node invasion (Table 2). The mean duration of postoperative hospitalization was $8.3 \pm 8.6$ (range, 2 to 71 ) days. The number of total operative mortality was three, and $45(22.2 \%)$ patients had operative complications. The most common complications were infection, transient arrhythmia, and hemorrhage. Forty-nine (24.1\%) patients were hospitalized for more than eight days due to complications. Postoperative pathological reports showing invasive tumor characteristics such as invasion to adjacent tissues $(n=48)$ and capsule $(n=52)$ or close surgical margins $(n=36)$ were the most common indications for the use of adjuvant treatment modalities. A total of $76(37.3 \%)$ and 25 patients (12.3\%) received adjuvant RT and adjuvant
CT, respectively. Four (2\%) patients with distant metastasis underwent CT with palliative intent.

\section{Recurrence and survival results}

Out of four patients with inoperable disease, complete follow-up data were available for 182 cases, and recurrence was observed in $30(16.5 \%)$ patients. Nineteen $(9.5 \%)$ patients died across all patient groups, and disease-related mortality was very low with seven patients (23.3\% of patients with recurrence). Three (1.5\%) patients died within one month after surgery. One $(0.5 \%)$ patient died on the first postoperative day due to hypotensive shock after extended surgery. The second patient died two weeks after surgery due to postoperative pneumonia and MG crisis. The last patient, previously diagnosed with chronic renal failure, died with infectious hemodialysis complications at the end of the first postoperative month. All patients with local recurrence in our cohort $(n=21)$ underwent a second surgery. Type of a second surgery depended on the region of recurrence, most frequently: lobectomy, pleurectomy, excision of the involved chest wall and rib. Although operative morbidity was relatively high $(47.6 \%)$, there was no operative mortality (Table 3 ).

At a mean follow-up of $198.2 \pm 6.5$ months $(95 \% \mathrm{CI}$ : 184.4-212), the five-year OS and DFS rates were $91.9 \%$ and $83.5 \%$, respectively. In the univariate analyses, higher Masaoka-Koga Stage $(\mathrm{p}<0.001), \mathrm{R} 1$ resection $(\mathrm{p}=0.042)$, and treatment with CT $(\mathrm{p}<0.001)$ were significant factors for decreased DFS (Table 4).
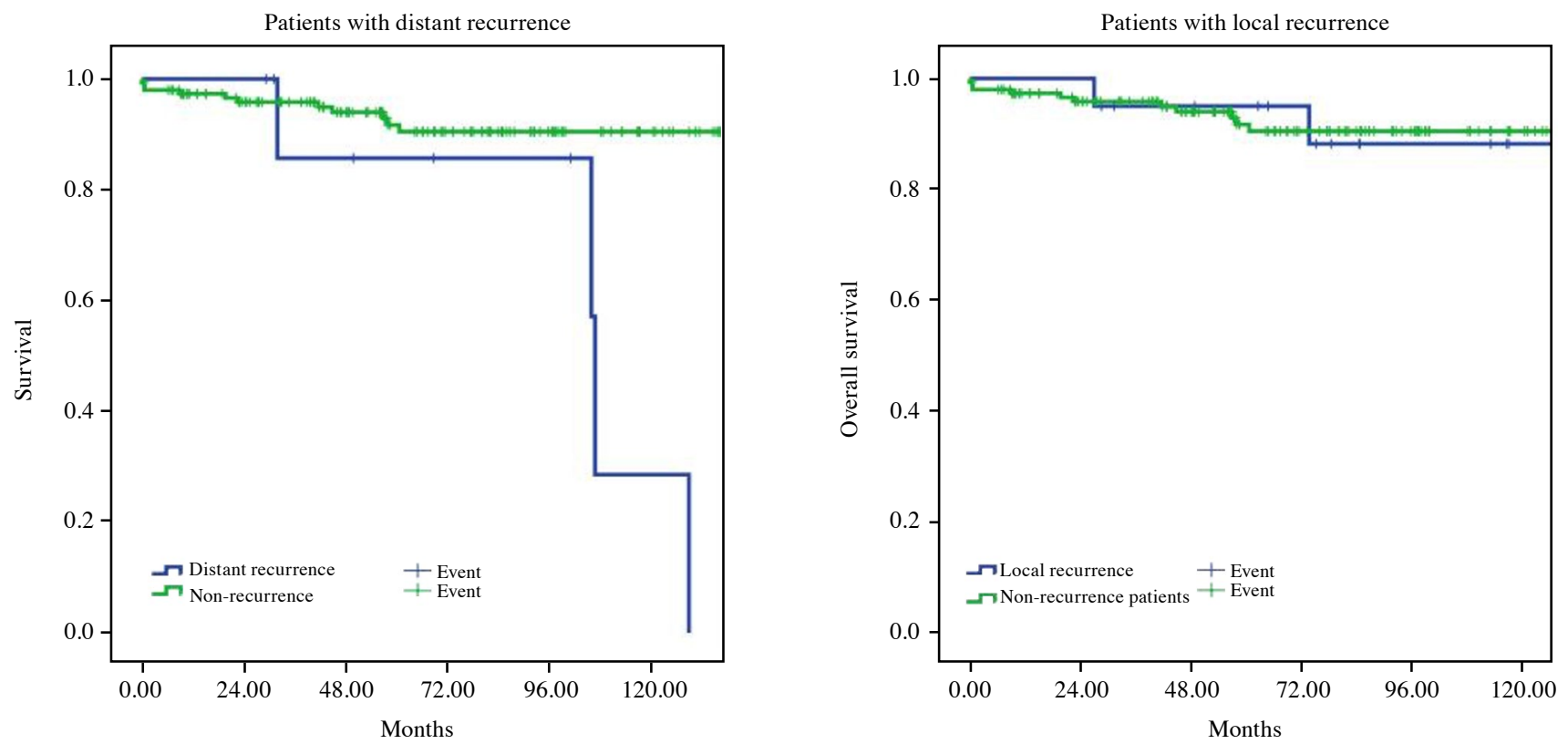

Figure 1. Survival results of patients after resection of local recurrence and distant recurrence. 
Table 5. Multivariate analysis of factors on survival

\begin{tabular}{|c|c|c|c|c|c|c|}
\hline \multirow[b]{2}{*}{ Factors } & \multicolumn{3}{|c|}{ Overall survival } & \multicolumn{3}{|c|}{ Disease-free survival } \\
\hline & HR & $95 \% \mathrm{CI}$ & $p$ & HR & $95 \% \mathrm{CI}$ & $p$ \\
\hline $\begin{array}{l}\text { Age } \\
\quad(\text { Ref: }<50)\end{array}$ & 4.265 & $1.349-13.479$ & 0.014 & 0.570 & $0.170-1.912$ & 0.362 \\
\hline $\begin{array}{l}\text { History of MG } \\
\text { (Ref: Yes) }\end{array}$ & 0.469 & $0.135-1.633$ & 0.234 & 0.918 & $0.308-2.740$ & 0.878 \\
\hline $\begin{array}{l}\text { Hospitalization time } \\
\text { (Ref: }<8)\end{array}$ & 3.815 & $1.282-11.353$ & 0.016 & 0.746 & $0.247-2.252$ & 0.603 \\
\hline $\begin{array}{l}\text { Histologic subtype } \\
\text { (Ref: A) }\end{array}$ & 0.714 & $0.444-1.148$ & 0.164 & 0.615 & $0.370-1.022$ & 0.061 \\
\hline $\begin{array}{l}\text { Neoadjuvant CT } \\
\text { (Ref: No) }\end{array}$ & 1.305 & $0.316-5.401$ & 0.713 & 0.907 & $0.273-3.013$ & 0.873 \\
\hline $\begin{array}{l}\text { Adjuvant CT } \\
\text { (Ref: No) }\end{array}$ & 0.590 & $0.112-3.100$ & 0.533 & 5.320 & $1.685-16.800$ & 0.004 \\
\hline $\begin{array}{l}\text { Adjuvant RT } \\
\text { (Ref: No) }\end{array}$ & 0.536 & $0.181-1.583$ & 0.259 & 2.097 & $0.774-5.680$ & 0.145 \\
\hline $\begin{array}{l}\text { Masaoka-Koga Stage } \\
\text { (Ref: II) }\end{array}$ & 2.955 & $1.452-6.016$ & 0.003 & 2.780 & $1.267-6.101$ & 0.011 \\
\hline
\end{tabular}

Ref: Reference value; HR: Hazard ratio; CI: Confidence interval; MG: Myasthenia gravis; RT: Radiotherapy; CT: Chemotherapy.

The MG history had a negative impact on DFS for patients with Masaoka-Koga Stage III, although the number of events was low ( $\mathrm{n}=7$, five-year DFS; $82.4 \%$ vs. $100 \%$, respectively; $\mathrm{p}=0.026$ ). For patients with Masaoka-Koga Stage IV disease, DFS rates were higher if they had a history of MG, but the results did not reach statistical significance (five-year DFS: $60.2 \%$ vs. $33.6 \%$, respectively; $\mathrm{p}=0.091$ ). Older age $(\mathrm{p}=0.043)$, higher Masaoka-Koga Stage $(\mathrm{p}=0.002)$, longer postoperative hospitalization $(\mathrm{p}=0.008)$, treatment with CT $(\mathrm{p}=0.046)$, and disease recurrence $(p=0.037)$ were significant factors for poor OS (Table 4). Notably, if the patients' first recurrence was local disease $(n=21)$, OS was similar to non-recurrent patients $(p=0.753)$ (Figure 1). The adjuvant RT resulted in statistically insignificant, but numerically higher OS rates in all patient populations (five-year OS: $93.6 \%$ vs. $89.5 \%$, respectively; $\mathrm{p}=0.315$ ). Only in patients with completely resected Masaoka-Koga Stage IV disease, was adjuvant RT found to have a significant positive effect on OS (five-year OS: 94.7\% vs. 79.1\%, respectively; $\mathrm{p}=0.015$ ). Adjuvant $\mathrm{CT}$, timing of adjuvant therapy (RT or CT), and histology showed no significant effects on patient outcomes. In the multivariate analysis, older age, higher MasaokaKoga Stage, and longer hospitalization time retained their prognostic significance on OS; Masaoka-Koga Stage and need for postoperative CT had prognostic significance for DFS (Table 5).

\section{DISCUSSION}

Although rare, thymomas constitute the most frequently occurring tumors of the anterior thoracic region. ${ }^{[3]}$ Due to its rarity and indolent course, retrospective experiences of reference centers are of utmost importance to understand the ailment and improve treatment recommendations. In this study, we present our experiences in the long-term in a highvolume reference center.

In our cohort, the median age of the patients was 49 years, and most patients presented with myasthenia-related symptoms. We observed significantly higher OS results in patients younger than 50 years old. Previous reports showing age-related outcomes have conflicting results. ${ }^{[10,13]}$ Upon diagnosis of MG, asymptomatic patients may be examined for thymoma, thereby, contributing to early detection. Based on this hypothesis, Wilkins et al. ${ }^{[14]}$ reported that MG was associated with a good prognosis. The effect of MG on survival is controversial, as is evident from other negative studies. ${ }^{[15,16]}$ In our cohort, there were two different results for Masaoka-Koga Stage III-IV disease, and it is difficult to comment on this association.

The current WHO classification is the most widely used system for histological classification..$^{[5,17]}$ Histological subtypes of thymoma not only show pathological results, but also provide information on 
the course of the disease. Although we were unable to show the survival effect of histological subtypes, we found that histology was strongly associated with the disease stage. Similar to our results, there have been a few reports demonstrating no relationship between OS and histology; ${ }^{[18,19]}$ however, some studies have shown a correlation. ${ }^{[12,20,21]}$ The relationship with disease stage could be interpreted as a survival result, when the cohort had a longer follow-up or higher sample size.

The implication of performing lymphadenectomy in patients is still controversial. However, the new Tumor, Node, Metastasis (TNM) staging system for thymic tumors prompts the recommendation for locoregional lymphadenectomy. ${ }^{[22]}$ In our study, we detected only five patients with metastasis on nodal evaluation. We were not able to evaluate the survival effect of lymph node metastasis due to the small number of patients. However, lymphadenectomy did not have an effect on treatment choice and survival in our cohort. In our patient population, the mean hospitalization duration was $8 \pm 8.5$ days. Interestingly, longer postoperative hospital stays were related to OS, evident from a multivariate analysis with a hazard ratio of 3.6. This could be attributed to the extensive nature of the surgery conducted. When we analyzed factors other than surgical complications that might affect the duration of hospitalization, age, history of $\mathrm{DM}$ or $\mathrm{MG}$, and disease histology were similar between the long and short hospitalized groups. Although multivariate analysis showed both disease stage and hospitalization time to be independent factors, clinically, they are not totally independent. This result may be used to relate surgical outcome to disease outcome and, for oncologists, it could be an indicator of the need for treatment and/or high frequency follow-up. Notably, more patients with Masaoka-Koga Stage IV disease and a history of neoadjuvant CT were hospitalized for eight days.

In the Surveillance, Epidemiology, and End Results (SEER) registry, adjuvant RT was associated with superior OS and DFS rates and subgroup analyses suggested that the OS benefit was limited to patients with Masaoka-Koga Stage III-IV disease. ${ }^{[23]}$ In our study, we found no survival benefit of adjuvant RT for Stage II-III, but in patients with completely resected Masaoka-Koga Stage IV disease, there was a significant survival benefit with adjuvant RT $(p=0.015)$. Moreover, only one patient with adjuvant RT within this subgroup $(n=38)$ died from the disease. The current data also have conflicting results for
CT as the sole adjuvant setting. Guidelines do not recommend postoperative $\mathrm{CT}$ for R0-R1 resected Stage I-IVA disease. ${ }^{[1]}$ We administered neoadjuvant and/or adjuvant $\mathrm{CT}$ to 48 patients, and if the patient had clinical indication of CT, they showed significantly lower survival rates. Consistent with our results, two separate studies also showed worse survival results with CT. ${ }^{[10,24]}$ However, these results may depend on the clinical characteristics of patients, leading to the employment of CT.

Recurrence of thymic tumors is not uncommon, with a rate of 10 to $15 \% .{ }^{[25]}$ Local recurrence is more common and should be managed as newly diagnosed tumors. ${ }^{[11]} \mathrm{A}$ total of $16.5 \%$ of our patients experienced recurrence after complete surgery, and recurrence was associated with lower OS ( $\mathrm{p}=0.013)$. Noteworthy, we demonstrated that patients with local recurrence subjected to a second surgery had survival rates equal to their non-recurrent counterparts. Therefore, we strongly suggest a second surgery for a diseasefree status. Patients are usually resistant to repeated surgeries; therefore, these results can be attributed to strong encouragement for patients to undergo surgery.

There are several limitations to this study. Patient selection bias was inevitable due to the retrospective nature of the study. However, this is one of the largest cohorts of thymoma in a single center, representing the comprehensive surgical, pathological, and oncological results of the patients. Considering the difficulties of performing prospective studies on this rare disease, retrospective real-life experiences are of clinically significant value for guiding treatment approaches.

In conclusion, higher Masaoka-Koga stage, age $\geq 50$ years, longer hospitalization time, and the need for chemotherapy are significantly correlated with worse survival results. More importantly, patients with Masaoka-Koga Stage IV disease can benefit from adjuvant radiotherapy, and resection of recurrent lesions has a significant effect on survival.

\section{Declaration of conflicting interests}

The authors declared no conflicts of interest with respect to the authorship and/or publication of this article.

\section{Funding}

The authors received no financial support for the research and/or authorship of this article.

\section{REFERENCES}

1. Detterbeck FC. Evaluation and treatment of stage I and II thymoma. J Thorac Oncol 2010;5(10 Suppl 4):S318-22.

2. Yanarateş A, Budak E. The role of positron emission tomography/computed tomography in the evaluation of 
anterior mediastinal masses and differentiating between the histological subtypes of thymic epithelial neoplasms. Turk Gogus Kalp Dama 2020;28:315-21.

3. Engels EA. Epidemiology of thymoma and associated malignancies. J Thorac Oncol 2010;5(10 Suppl 4):S260-5.

4. Bernard C, Frih H, Pasquet F, Kerever S, Jamilloux Y, Tronc F, et al. Thymoma associated with autoimmune diseases: 85 cases and literature review. Autoimmun Rev 2016;15:82-92.

5. Marx A, Chan JK, Coindre JM, Detterbeck F, Girard N, Harris NL, et al. The 2015 World Health Organization classification of tumors of the thymus: Continuity and changes. J Thorac Oncol 2015;10:1383-95.

6. Koga K, Matsuno Y, Noguchi M, Mukai K, Asamura H, Goya $\mathrm{T}$, et al. A review of 79 thymomas: Modification of staging system and reappraisal of conventional division into invasive and non-invasive thymoma. Pathol Int 1994;44:359-67.

7. Masaoka A. Staging system of thymoma. J Thorac Oncol 2010;5(10 Suppl 4):S304-12.

8. Kondo K. Tumor-node metastasis staging system for thymic epithelial tumors. J Thorac Oncol 2010;5(10 Suppl 4):S352-6.

9. Detterbeck FC, Zeeshan A. Thymoma: Current diagnosis and treatment. Chin Med J (Engl) 2013;126:2186-91.

10. Jackson MW, Palma DA, Camidge DR, Jones BL, Robin $\mathrm{TP}$, Sher DJ, et al. The impact of postoperative radiotherapy for thymoma and thymic carcinoma. J Thorac Oncol 2017;12:734-44.

11. Girard N, Ruffini E, Marx A, Faivre-Finn C, Peters S; ESMO Guidelines Committee. Thymic epithelial tumours: ESMO Clinical Practice Guidelines for diagnosis, treatment and follow-up. Ann Oncol 2015;26 Suppl 5:v40-55.

12. Liu Q, Gu Z, Yang F, Fu J, Shen Y, Wei Y, et al. The role of postoperative radiotherapy for stage I/II/III thymic tumorresults of the ChART retrospective database. J Thorac Dis 2016;8:687-95.

13. Venuta F, Rendina EA, Pescarmona EO, De Giacomo T, Vegna ML, Fazi P, et al. Multimodality treatment of thymoma: A prospective study. Ann Thorac Surg 1997;64:1585-91.

14. Wilkins KB, Sheikh E, Green R, Patel M, George S, Takano $\mathrm{M}$, et al. Clinical and pathologic predictors of survival in patients with thymoma. Ann Surg 1999;230:562-72.

15. Su XY, Wu WL, Liu N, Zhang SF, Li GD. Thymic epithelial tumors: A clinicopathologic study of 249 cases from a single institution. Int J Clin Exp Pathol 2014;7:7760-7.

16. Park MS, Chung KY, Kim KD, Yang WI, Chung JH, Kim YS, et al. Prognosis of thymic epithelial tumors according to the new World Health Organization histologic classification. Ann Thorac Surg 2004;78:992-7.

17. Travis WD, Brambilla E, Burke AP, Marx A, Nicholson AG. Introduction to The 2015 World Health Organization classification of tumors of the lung, pleura, thymus, and heart. J Thorac Oncol 2015;10:1240-2.

18. Julka PK, Sharma DN, Mallick S, Gandhi AK, Joshi NP, Haresh KP, et al. Outcomes of thymoma treated with multimodality approach: A tertiary cancer center experience of 71 patients. Tumori 2017;103:572-6.

19. Safieddine N, Liu G, Cuningham K, Ming T, Hwang D, Brade A, et al. Prognostic factors for cure, recurrence and long-term survival after surgical resection of thymoma. J Thorac Oncol 2014;9:1018-22.

20. Prokakis C, Koletsis E, Apostolakis E, Zolota V, Chroni $\mathrm{E}$, Baltayiannis $\mathrm{N}$, et al. Modified maximal thymectomy for thymic epithelial tumors: Predictors of survival and neurological outcome in patients with thymomatous myasthenia gravis. World J Surg 2009;33:1650-8.

21. Chen G, Marx A, Chen WH, Yong J, Puppe B, Stroebel P, et al. New WHO histologic classification predicts prognosis of thymic epithelial tumors: A clinicopathologic study of 200 thymoma cases from China. Cancer 2002;95:420-9.

22. Detterbeck FC, Stratton K, Giroux D, Asamura H, Crowley J, Falkson C, et al. The IASLC/ITMIG Thymic Epithelial Tumors Staging Project: Proposal for an evidence-based stage classification system for the forthcoming (8th) edition of the TNM classification of malignant tumors. J Thorac Oncol 2014;9(9 Suppl 2):S65-72.

23. Lim YJ, Kim HJ, Wu HG. Role of postoperative radiotherapy in nonlocalized thymoma: Propensity-matched analysis of surveillance, epidemiology, and end results database. J Thorac Oncol 2015;10:1357-63.

24. Zhao M, Yin J, Yang X, Jiang T, Lu T, Huang Y, et al. Nomogram to predict thymoma prognosis: A populationbased study of 1312 cases. Thorac Cancer 2019;10:1167-75.

25. Carretta A, Ciriaco P, Muriana P, Bandiera A, Negri G. Surgical treatment of single and multiple thymoma recurrences. Gen Thorac Cardiovasc Surg 2020;68:350-6. 